\title{
A literatura polêmica judaico-cristã na Idade Média
}

\author{
Nachman Falbel \\ Departamento de História da FFLCH da Universidade de São Paulo
}

Na literatura medieval encontramos um gênero típico daquele período histórico o qual é conhecido pela sua particular importância para o estudo das relações entre judeus e cristãos: trata-se da literatura polêmica, escrita tanto por judeus quanto por cristãos.

Em boa parte os textos que chegaram até nós são resultados de encontros havidos entre os representantes das duas religiões, encontros esses organizados pelas autoridades seculares e com a participação da instituição eclesiástica, que normalmente toma a iniciativa para possibilitar o confronto teológico entre as duas fés. Mas boa parte dos textos, sejam eles escritos por judeus ou por cristãos, são fruto de uma atividade literária pura, ou seja, sem que seus autores tenham participado de qualquer polêmica organizada em determinado tempo e lugar, ainda que possam inspirar-se em encontros havidos no passado próximo ou longínquo.

Claro é que a polêmica tem como objetivo último a conquista ou a conversão do oponente, e no caso os membros da religião minoritária judaica à religião cristã, partindo-se da suposição que a conquista e a conversão de adeptos de outra religião é a melhor demonstração de sua superioridade. Além do mais o cristianismo medieval tinha um ideal de unidade religiosa abrangente onde não cabiam heréticos e nem tão pouco outras religiões, mesmo que Santo Agostinho no século IV tenha definido os judeus como o "testemunho vivo" da nova fé e portanto sancionado a sua existência no meio da cristandade. Nessa "altercatio ecclesiae et synagogam" não deixá de haver um aspecto lúdico-espiritual quando se trata de um confronto de dois adversários em público, frente uma assistência de clérigos, nobres, burgueses e judeus que em seus corações procuram 
a vitória ou pelo menos a não-derrota de seus representantes. Esse aspecto lúdico-espiritual é menos visível no escrito polêmico propriamente dito ainda que se preserve a tensão espiritual implícita no jogo dos argumentos a favor e contra, aregimentados pelos autores.

Por outro lado temos a observar que o escrito polêmico não é exatamente um tratado teológico fruto da escolástica medieval, apesar de tratar da discussão dos artigos da fé onde se abordam questões teológicas relativas ao monoteismo e à concepção trinitária da divindade, da trancedência divina e da encarnação, do livre-arbítrio e da providência, etc. Mas não somente os fundamentos da fé são objeto da redação polêmica, porém o próprio culto e seus aspectos externos podem servir de argumento de um e outro lado.

Podemos nesse sentido classificar os argumentos em dois tipos: os da razão (ratio) e os de autoridade (auctoritas). O primeiro tipo de argumento é na verdade especulativo, e se assenta sobre o raciocínio teológico-filosófico que recorre muitas vezes à utilização da lógica aristotélica transformada em um dos principais instrumentos intelectuais do mundo medieval. O segundo tipo de argumento é extraído diretamente das Escrituras sagradas - dai o termo auctoritas - pois são elas que dão validade aos artigos da fé ou às discussões ao redor deles. Tanto para os judeus quanto para os cristãos importante é interpretar os versículos bíblicos apropriados aos pontos em discussão ou polêmicos de modo que venham confirmar favoravelmente as verdades religiosas em questão. Portanto o "texto sagrado" é objeto de interpretação do escrito polêmico e assim sendo o autor do mesmo necessita conhecê-lo profundamente e mais do que isso necessita estar munido da tradição exegética acumulada durante séculos por ambas as religiões, isto é do cristianismo e do judaismo. Sob esse aspecto não basta apenas o conhecimento exegético porém requer também o conhecimento linguístico do hebraico, do latim e do grego, o que nem sempre ocorreu durante a Idade Média pois, no caso do hebraico poucos cristãos, com exceção dos conversos, o dominavam. Dai também encontrarmos com frequência entre os polemistas cristãos, por ocasião de um confronto público, e também autores de escritos, conversos judeus que naturalmente se mostravam bons conhecedores da literatura rabínica. Mesmo assim a Igreja se preocupou em criar "escolas" de preparação de polemistas onde o preparo linguístico fazia parte do currículo e os escritos polêmicos serviam como textos de estudo aos seus participantes. A partir do século XIII tais escolas que visavam também preparar missionários que deveriam atuar entre judeus, muçulmanos e outras religiões, eram eficientes centros de preparo para o proselitismo cristão bem como para a formação de polemistas. Essas escolas fundadas por dominicanos e franciscanos tiveram um papel importante no ensino e na difusão da língua hebraica na Europa ocidental. Basta mencionarmos a escola de línguas orientais de Raimundo Martí que se destacou como um dos polemistas 
mais argutos da Espanha cristã e que deixou um texto polêmico famoso, o Pugio fidei adversus iudaeos (A espada da fé contra os judeus), onde demonstra extraordinário conhecimento da literatura rabínica. Do "Studium hebraicum" de Raimundo Martí, em Barcelona, sairam outros polemistas entre os quais o genial médico e místico Arnaldo de Vilanova, que escreveu o Allocutio super Tetragrammaton (Discurso sobre o nome da divindade) onde demonstra ter certo conhecimento do hebraico (1). Mais tarde o Concílio de Viena (1311-1312) determinará a obrigatoriedade do estudo do hebraico, do árabe e do aramaico nas universidades européias .

Sendo as Escrituras Sagradas a principal fonte para o escrito polêmico e que dá validade aos argumentos utilizados por ele, vem a ser importante e decisivo o reconhecimento do método de interpretação adotado pelos contendores. E aqui existem duas tradições opostas quanto ao método de interpretação da Bíblia, pois de um lado os cristãos tendem a adotar o método alegórico ou seja por meio de símbolos e figuras que dão asas à imaginação do exegeta, enquanto que os judeus tendem tradicionalmente a adotarem o método literal que implica no conhecimento do significado do termo, da palavra ou ainda de seu sentido histórico. Mas do ponto de vista da história da exegese, tanto a cristã quanto a judaica, apresentaram métodos de interpretação semelhantes ainda que as tendências diferenciadoras predominantes são as que mencionamos acima. Os polemuitas conscientes das diferenças dos métodos de interpretação adotados por ambas as partes tentarão invalidá-los assim como se esforçarão em demonstrar que as traduções das Escrituras Sagradas, deturparam o seu sentido original e portanto não merecm fé. Os judeus acentuarão este aspecto pois recorrerão ao argumento básico de que o Velho Testamento foi escrito em hebraico no seu original e o espírito de Deus se manifestou nessa língua e não em outra, e as traduções feitas posteriormente foram fruto da vontade do homem apenas. Daí rejeitarem os argumentos apoiados na Vulgata de São Jeronimo e na Septuaginta. Em um texto polêmico escrito na Inglaterra, no século XI, onde tomam parte num debate Gilbert Crispin e um judeu de Mogúncia, este respónde ao seu interlocutor cristão que jamais ouviu falar sobre os setenta sábios que sob Ptolomeu traduziram a Bíblia do hebreu ao grego, e Crispin lhe responderá que quando foi feita a tradução não existiam cristãos, portanto não poderá haver qualquer suspeita da falsificação.

Algumas passagens ou versículos bỉblicos são centrais nos textos polêmicos e são objetos de interpretação que poderão favorecer a um ou outro lado. Dentre eles encontramos os versículos do Gen. I, 26, onde

(1) - Sobre esse aspecto escrevemos em nossa tese de livre-docência Arnaldo de Vilanova, sua doutrina reformista e sua concepção escatológica, Universidade de São Paulo, 1977. 
se emprega o plural na expressão "Façamos o homem à nossa imagem..." e que para o polemista cristão é uma demonstração da Trindade; o vèrsículo do Gen. XLIX, 10, "O cetro não se arredará de Judá, nem o legislador dentre seus pés, até que venha Siló; e a ele se congregarão os povos" o que para o cristão significa a vinda de Cristo e o domínio da Igreja; Isaias, VI, 3, onde nas palavras "... dizendo: Santo, santo, santo..." se anuncia a Trindade, etc.

Mas nem sempre a discussão e o escrito polêmiço se mantêm no plano teológico pois em boa parte o texto adota um tom apaixonado no estilo próprio do sermão medieval, onde acusações de toda a natureza aos judeus são proferidos enfatizando-se a sua obstinação, o seu abandono, a sua dispersão, a sua escravidão, etc. No fundo tais acusações incorporadas aos textos polêmicos seguem uma longa tradição literária que remonta aos tempos dos Padres da Igreja ou aos próprios inícios do cristianismo.

Em parte podemos encontrar as mesmas acusações feitas aos cristãos durante o período em que foram perseguidos pelos pagãos romanos retomadas por sua vez pelos cristãos para as usarem contra os judeus. Nesse sentido houve uma mudança de alvos mas não de argumentos (2).

As fontes literárias anti-judaicas no período que vai de Hadriano até Constantino continuam a linha de ataques aos judeus, inspiradas em certos versículos do Novo Testamento que em parte repetem as apóstrofes dos profetas contra Israel para provarem a vinda do Messias, a punição, a decadência e a servidão dos judeus depois da paixão de Cristo. Justino Martir, no diálogo com Trifon, cujo texto foi escrito aproximadamente entre 156 e 161 de nossa era, vê a destruição realizada pelos romanos na Palestina como o castigo de Deus e mesmo os preceitos judaicos são vistos como uma punição, entre eles, o de guardar o sábado (3). No escrito de Orígenes, Contra Celsum, encontramos essa linha que é complementada por outros que procuram demonstrar que os judeus foram substituidos pelos cristãos e cairam na servidão, como castigo, recorrendo a certas provas tais como a destruição de Jerusalém e as medidas ou leis anti-judaicas dos imperadores romanos. Dessa forma os cristãos constituem o Verus Israel, o verdadeiro Israel.

E fundamentalmente a partir de Constantino que os ataques aos judeus incorporam os argumentos que os pagãos utilizaram contra os cris-

(2) - E preciso observar que os escritores pagãos gregos e latinos também se referiram aos judeus nos mesmos termos que se referiram aos cristãos. Veja-se a esse respeito Reinach, Théodore, Textes d'auteurs grecs et romains relatifs au judaisme, Hildesheim, Georg Olms, 1963. Também o trabalho mais recente de Stern, M., Greek and Latin authors on Jews and Judaism, Jerusalém, 1974.

(3) - V. verbete "Disputation and Polemics", in: Encyclopaedia Judaica, Keter Publishing Society, 1971, escrito por H. Ben-Sasson. 
tãos, a começar do uso de expressões relativas ao culto "triste e frio", adoram anjos, desprezam as imagens, praticam a circuncisão, observam o sábado, observam regras sobre os alimentos, mas também são acusados de ateismo (impia gens), de falta de respeito perante o imperador, de misantropia, de abandono pela divindade, de inúteis, de nação feita para a escravidão, de sediciosos, etc. Nos escritos dos Padres Apostólicos, nos dos Apologistas do século II, nas constituições e cânones pseudo-apostólicos e nas obras dos Padres da Igreja encontram-se disseminados esses elementos que formarão o arsenal polêmico anti-judaico num período posterior, ou seja em plena Idade Média (4).

Um dos primeiros escritos polêmicos no ocidente medieval e que influenciou a outros posteriormente foi elaborado por Isidoro de Sevilha (c. 560-636) mais tarde canonizado como santo e considerado um dos doutores da Igreja. Isidoro de Sevilha escreveu o tratado De fide catholica contra Iudaeos, entre outros escritos, que tinham finalidade polêmica, tais como o Isaiae Testimonia de Christo Domino e o Liber de variis quaestionibus adversus Iudaeos, e que visavam além de converter judeus ao cristianismo fortificar os conversos em sua nova fé, uma vez que a política conversionista do reino vivsigótico forçou muitos judeus a abandonarem a sua religião. O texto de Isidoro de Sevilha se difundiu pela Europa e já no século VIII temos uma tradução do De fide catholica traduzida ao alemão medieval. Porém não devemos supor que antes de Isidoro de Sevilha não houve escritos polêmicos anti-judaicos pois os encontramos desde os primórdios da Alta Idade Média, a partir do século IV (5).

Na Baixa Idade Média, ou seja, a partir do século XII, os tratados tornam-se mais extensos e mais sistemáticos, isso devido a três fatores principais: a) à disseminação de heresias populares que exigem da Igreja uma defesa dos principios da fé; b) à atividade conversionista católica que recrudesce nesse período, e como já dissemos mais acima, visando muçulmanos, heréticos e judeus; c) às disputas verbais que são estimuladas e tornam-se mais frequentes. Vejamos agora alguns tratados polêmicos, e seus autores, que tiveram certo destaque dentro desse gênero literário, a começar dos tratados cristãos. Lembremos em primeiro lugar o escrito Disputatio Iudei et Christiani, já mencionado, de Gilbert Crispin (c. 1046-1117), que foi abade de Westminster e discípulo do arcebispo Anselmo de Canterbury. $\mathrm{O}$ seu escrito é dedicado ao arcebispo e foi redigido antes de 1096. O nível da discussão é elevado e o judeu é elogiado por Crispin pela sua profunda erudição, judaica e cristã, ao mesmo tempo que ele tem

(4) - A melhor coletânea nesse sentido é de Williams, A. L., Adversus Judaeos, Cambridge, 1935.

(5) - Veja-se a admirável obra Blumenkranz, B., Les auteurs chrétiens latins du Moyen Age sur les juifs et le judaisme, Paris-La Haye, Mouton \& Co., 1963. Também o estudo de Browe, P., Die Judenmission im Mittelalter und die Papste, Roma, 1942. 
a inteira liberdade de expor seus argumentos com largueza. O mesmo texto sofreu alterações de estilo no século XII e o tom amistoso do original tornou-se duro e rancoroso em relação ao judeu, chegando-se mesmo a diminuir a força de seus argumentos. Outro abade, de Cluny, Pedro, o Venerável (c. 1090-1156) homem de grande influência em seu tempo, esteve na Espanha e escreveu, além de dois tratados polêmicos contra o Islão, um tratado anti-judaico o Adversus Judaeorum inveteratam duritiam, em forma de diálogo. No seu escrito ele menciona também que teve a oportunidade de manter disputas verbais com judeus. Seu escrito foi muito difundido durante a Idade Média.

Merece também menção o escrito polêmico do teólogo Pedro de Blois (c.1135-c.1204) que, apesar de ter nascido na França viveu na Inglaterra onde escreveu o Liber contra perfidiam Judaeorum, a pedido de um amigo que vivia próximo a heréticos e judeus que o desafiavam a polemizar com eles sem que se sentisse preparado para tanto. E um texto rico pelas citações dos Padres da Igreja, de autores judeus e pagãos, incluindo uma citação de um texto sibilino.

Ainda no século XII encontramos outros textos menos expressivos e publicados em várias coleções de escritos eclesiásticos (6), entre eles temos o De incarnatione adversus Juadaeos, de Gilbert, abade de Nogent (1104-1124); Annulus, seu Dialogus Christiani et Judaei de fidei sacramentis, de Rupert (1120-1135); um Altercatio Judaei cum Christiano de fide christiana, dirigida a Alexandre, bispo de Lincoln (1123-1148) e atribuída falsamente a Guilherme de Champeaux e ainda uma Disputatio ecclesiae et sinagogae, escrita por Gilbert de Tournai e publicada por Martène e Durand (7) .

No século XIII realizam-se grandes e pomposas disputas verbais que estimulam novos escritos. Quase sempre são apóstatas judeus que defendem a religião cristã e isso decorrente de um processo de conversões que se tornam mais intensas à medida que as pressões sobre as comunidades judias aumentam. Nesses debates os antigos argumentos cristãos somam-se aos argumentos caraitas que negavam o Talmud e portanto fornecem aos polemistas cristãos material para ser usado contra os seus adversários. Dentre essas disputas vale ressaltar a realizada em Paris, em 1240 entre o apóstata Nicolas Donin e o tosafista Yechiel ben Yosef de Paris, debate esse que se concentrou ao redor do Talmud e seu conteúdo, e que resultou no fim na queima do Talmud em praça pública, como resultado de um "julgamento" ganho pelo lado mais forte. Na Espanha, em 1263, teve lugar a famosa disputa de Barcelona, entre o apóstata Pablo Christiani

(6) - Lembrados por Levi, Israel, Controverse entre um juif et un chrétien au XIe siècle, Revue des Etudes Juives, V, no 10, pp. 238-245.

(7) - Martène, E, e Durand, U., Thesaurus novus anecdotorum, 5 vol., Paris, 1717, pp. 1497-1506. 
e Moshe ben Nachman (Nachmanides) que resultou na necessidade do Ramban abandonar a Espanha e se dirigir a Terra Santa. O debate dessa vez centrou-se na questão messiânica sendo que o texto hebraico da polêmica realizada na presença do rei de Aragão, Jaime II, se conservou ee foi publicado várias vezes.

Ainda na Espanha e no mesmo século, em 1284, realizou-se o debate entre o já mencionado autor do Pugio Fidei, Raimundo Martí e a maior autoridade rabínica daquele tempo, Schlomo ben Aderet. Esse clima polêmico da época se explica em boa parte devido às resoluções canônicas do IV Concilio de Latrão, de 1215, que procurou assumir uma atitude combativa em relação a heréticos e infiéis procurando conquistar adeptos da religião judaica e muçulmana. Por outro lado as ordens Dominicana e Franciscana, contribuiram em muito, no seu afã de catequese, para a disseminação do espírito polêmico em toda a Europa.

No decorrer do século XIV, ainda na Espanha, onde as relações entre judeus e cristãos foram se deteriorando até a explosão que levou à destruição das aljamas em 1391, vários escritos que datam dos inícios daquele século, do ano de 1305, é o Liber Praedicationis contra Judaeos do catalão Raimundo Lullio, (8) que era um proselitista ardoroso e que polemizou incessantemente com muçulmanos. Um texto escrito em 1317, aproximadamente, é o tratado de Bernardo Oliver, da ordem dos Agostinhos, e que viveu em Valença destacando-se como grande pregador. Em sua obra Contra caecitatem Judaeorum (9) (Contra a cegueira dos judeus) utiliza-se de citações de Flavius Josefus, de Isidoro de Sevilha e também de Maimonides. Supõe-se que sua obra tenha servido como manual de preparo a polemistas e tenha influenciado um texto menos conhecido, de caráter anti-judaico escrito pelo aragonês Jaime Giveroso, entre 1.334-35, com o título Liber $X X X$ Dei verborum. O saudoso professor Francisco Cantera Burgos, que editou o texto de Bernardo Oliver, crê que há certos indícios de sua obra ter influenciado a disputa havida entre o cardeal Pedro de Luna (depois papa Benedito XIII) e Shem Tov ben Itzchag Shaprut, de Tudela, realizada em 1380-84, e mesmo a famosa disputa de Tortosa, que se realizou entre 1413-14 e que foi organizada por esse mesmo Papa, a qual decidiu, em parte o destino das comunidades judias de Aragão. Essa seria uma das últimas grandes disputas públicas cuja dramaticidade podemos imaginar perante um espetáculo onde os representantes da comunidade foram obrigados a assistirem os ataques e as calúnias do Apóstata Jeronimo de Santa Fé, anteriormente Yeoshua Lorki. O mesmo Jeronimo de Santa Fé escreveu, após a sua conversão, dois tratados

(8) - Editado por J. M. Miliás Vallicrosa, C.S.I.C., Instituto Arias Montano, Madrid-Barcelona, 1957.

(9) - Editado por Francisco Cantera Burgos, C.S.I.C., Instituto Arias Montano, Madrid-Barcelona, 1957. 
polêmicos anti-judaicos, o Contra perfidiam Judaeorum e o De Judaeis erroribus ex Talmuth. E sabido que a atitude de Yeoshua Lorki em abraçar o cristianismo foi influenciada por seu mestre o apóstata Pablo de Santa Maria de Burgos (c. 1350-1435), anteriormente Schlomo Halevi, pertencente a uma família judaica proeminente do reino de Castela. Ele escreveu um tratado apologético, o Scrutinium Scripturarum, em forma de diálogo entre um judeu, Saul, e um cristão, Paulo, no estilo dos tratados polêmicos já mencionados. Como formando uma corrente de apóstatas, onde um influenciou a atitude de outro, Schlomo Halevi teve como exemplo anterior, e que calou fundo no judaismo de seu tempo, a conversão do apóstata Avner de Burgos (c. 1270-1340), que adotou o nome cristão de Alfonso de Valladolid, personagem que se debateu tragicamente durante muitos anos frente a dúvidas sobre a sua verdadeira fé. Mais tarde ele tornar-se-ia um fanático polemista chegando a disputar verbalmente com Moses bem Yoshua de Narbonne, e escrevendo vários tratados antijudaicos, dos quais o mais importante é o More Tzedek (Guia da Justiça), que se preservou em uma tradução castelhana com o título Mostrador de Justicia, ao par de um outro tratado, Minchat Kenaot (Sacrifício desprezível), que tinha por intenção revidar ao trabalho de seu discípulo Itzchaq ben Yosef ibn Pulgar onde refutou os argumentos que levaram o seu mestre a converter-se ao cristianismo. A literatura polêmica e apologética judaica tem seus inícios no próprio tempo em que a religião cristã surgiu como uma seita e que se distanciava mais e mais do judaismo tradicional ao ponto de chamar a atenção dos sábios da época. Assim encontramos no Talmud referências aos "minim" (cristãos) (10) sobre aspectos ligados as crenças básicas dos judeus e a menção de interpretações que os cristãos faziam de certas expressões bíblicas. Claro é que durante a Idade Média os judeus tiveram que se defrontar não somente com os cristãos mas também com samaritanos, caraitas, muçulmanos, gerando dessa forma escritos polêmicos contra os mesmos. E muitas vezes a literatura polêmica ou apologética cristã também soubz aproveitar os argumentos das seitas e religiões acima mencionadas incorporando-os aos seus escritos e manejando-os com habilidade contra os judeus. De outro lado, com o passar do tempo, foi acumulando-se uma vasia literatuar apologética judaica que servia de instrumento de defesa e dava alento espiritual as comunidades da Diáspora em momentos que a polêmica ou o confronto polêmico com o cristianismo era inevitável. Um dos escritos importantes nesse sentido foi o Sefer emunot ve-deot (Livro das crenças e concepções) de Saadia Gaon, no qual encontramos uma verdadeira exposição dos princípios e crenças do judaismo, e onde argumenta-se também contra os filosofos cristãos.

(10) - O termo "minim" pode também significar heréticos em geral ou pagãos. E necessário estar atento ao significado para sabermos quando o texto talmúdico se refere a cristãos ou não. 
Também certos fragmentos polêmicos encontrados na Genizá do Cairo e remontando pelo menos aos inícios do século $\mathrm{X}$ atestam o confronto com o cristianismo (11). E conversos, como David al-Mukammis, que retornaram ao judaismo, também escreveram tratados anti-cristãos.

Entre as obras apologéticas que provocaram grande eco no judaismo medieval foi o Sefer Ha-Kuzari (O livro do Kázaro) do poeta-filosofo Yehuda Halevi onde se relata a conversão do rei da Kazaria ao judaismo após tèr inquirido sobre as verdades das religióes cristã e muçulmana. 0 olhar de Yehuda Halevi sobre a história do povo judeu e seu destino como povo eleito de Deus constituem as linhas mestras do escrito do filósofo e acredita ainda que os demais povos em tempo vindouros com a vinda do Messias também aderirão ao judaismo. Mais característica como obra polêmica e cujo método é próprio a esse gênero de literatura é o escrito de Jacob ben Reuven, o Sefer Milchamot Adonai (Livro das guerras de Deus), escrito em 1170, no qual se mencionam autores judeus anteriores como Saadia Gaon, Abraham bar Hyia, e Abraham ibn Ezra. Por ser um dos mais antigos no gênero ele serviu de modelo a outros polemistas na Espanha. A obra foi escrita para responder a um clérigo, amigo do autor, que foi seu contendor amistoso em discussões sobre religião. $O$ texto possui doze capítulos formados essencialmente sobre os livros da Bíblia que tem a haver com os argumentos utilizados nos escritos polêmicos.

Na França, a partir do século XIII, várias obras apologéticas foram escritas a começar do Milchemet Mitzvá (Guerra justa) de Meir ben Shimon, de Narbonne cujo texto é muito rico em informações sobre a vida dos judeus naquela região.

Os exegetas judeus da França em seus comentários também procuraram nas passagens que davam margem a interpretações cristológicas fazer explanações que podemos considera-las como polêmicas e apologéticas. Tais explanações se encontram nos comentários bíblicos de Rashi, de Schmuel ben Meir, de Yosef ben Itzchag Bechor Schor e nos de Eleazar de Beaugency (12). A hermeneutica utilizada pelos comentadores hebreus segue o método literal (peshat) associado a interpretações casuísticas, incluindo métodos tradicionais de numerologia (gematria) e abreviações (notarikon) comumente usados pelos judeus. $\mathrm{O}$ caso mais extremado, e constituindo um comentário bíblico com fins polêmicos, é o Teshuvot ha-Minim (Respostas aos cristãos), de Josef ben Nathan Official, escrito aproximadamente em 1260 . No fundo o texto reflete o aumento da ativi-

(11) - V. artigo de Jacob Mann, Hebrew Union College Annual, 12, 1938. pp. 427 ss.

(12) - V. verbete "Apologetics", in Encyclopaedia Judaica, Keter Publishing Society, 1971 . 
dade proselitista cristã e a consequente exigencia ou necessidade de auto-defesa espiritual do judaismo daquele tempo.

Sob esse aspecto a Espanha, onde se deram, principalmente a partir do século XIV, o maior número de apostasias, e significativas do ponto de vista da projeção desses conversos, pois eram rabinos de certo renome nas judiarias ibéricas, foi o lugar onde proliferou a literatura polêmico-apologética. Assim em resposta a conversão de Avner de Burgos, lembrado acima, Itzchaq Pollegar (Pulgar) escreveu a sua Igeret ha-Charafot (Epístola das acusações) que se difundiu e circulou nas comunidades espanholas, além de um tratado mais completo com o título de Ezer ha-Dat (Auxílio da Religião). No decorrer do século vários outros trabalhos foram escritos para se contrapor a apostasia e merecem ser lembrados - Ezer ha-Emuná (Auxílio da Fé) de Moisés ha-Kohen de Tordesilhas, que o escreveu em 1375; o Even Bochan, de Shem Tov ben Itzchaq ibn Shaprut, escrito em 1385, e outros . Após a destruição das comunidades judias em 1391, quando a atividade polêmica tornou-se mais aguda, temos uma obra apologética importante escrita pelo filósofo Chasdai Crescas com o título Bittul Ikarei ha-Notzrim (Anulação dos principios cristãos). Na sua obra filosófica mais conhecida, Or Adonai, (Luz divina) ele também faz uma defesa do judaismo em nível filosófico onde o núcleo central de sua polêmica se faz contra o racionalismo e o averroismo, acentuando o caráter reditivo do judaismo através da fé e do cumprimento dos preceitos (mitzvot).

No mesmo período um discípulo de Chasdai Crescas, Profiat Duran, escreveu em estilo satírico e sutil uma carta contra o cristianismo como dirigida a um amigo que se converteu à religião cristã, com o título $A l$ tehi ka-avoteicha (Não sejais como nossos antepassados) além de um tratado com o nome de Klimat ha-goim (Confusão dos gentios) em que procura demonstrar que o cristianismo antigo é um conglomerado de concepções errôneas adotadas por pessoas ingênuas, exploradas e complementadas mais tarde por "herdeiros" que deram àquela religião a presente forma.

Já após a Disputa de Tortosa, de 1413-14, 'e que provocou o surgimento de novos escritos polêmicos, divulgou Shimon Zemach Duran, em 1423, o seu Keshet $u$-Magen (Arco e Escudo).

O médico Chaim Ibn Musa, escreveu, aproximadamente em 1460, um manual bem ordenado com o fim de servir às disputas dos judeus, com o título de Magen va-romach (Escudo e lança) orientado contra os escritos de Nicolau de Lyra e os escritos dos apóstatas, influenciado em muito por Chasdai Crescas.

Mas não somente na Espanha, porém na Alemanha e Itália, durante o século XV continuaram as polêmicas judaico-cristãs e um dos textos 
polêmicos mais significativos escritos aproximadamente em 1410 é o Sefer ha-itzachon (Livro da Vitória) de Yomtov Lipmann Muelhausen bem como o Teshuvat ha-minim u-shear inyanim (Resposta aos cristãos e outras questões) que serve de apêndice a obra Meshivat nefesh (Conforto e alma) de Yochanan Luria. Na Itália, Abraham Farissol (c.1451-.1525), por ordem do duque de Ferrara, lugar onde viveu, teve que representar o judaismo em uma polêmica com dois monges dominicanos, e cujo resultado influenciou o seu escrito Maguen Avraham (Escudo de Abrão) que represẹta ser um manual de polêmica anti-cristã e anti-muçulmana.

Sabemos que a polêmica judaico-cristã não terminará com a Idade Média mas seguirá seu curso histórico até os tempos mais recentes se bem que não tendo mais o caráter formal do passado e tão pouco acompanhada dos temores que faziam parte da vida judaica na sociedade cristã medieval. 